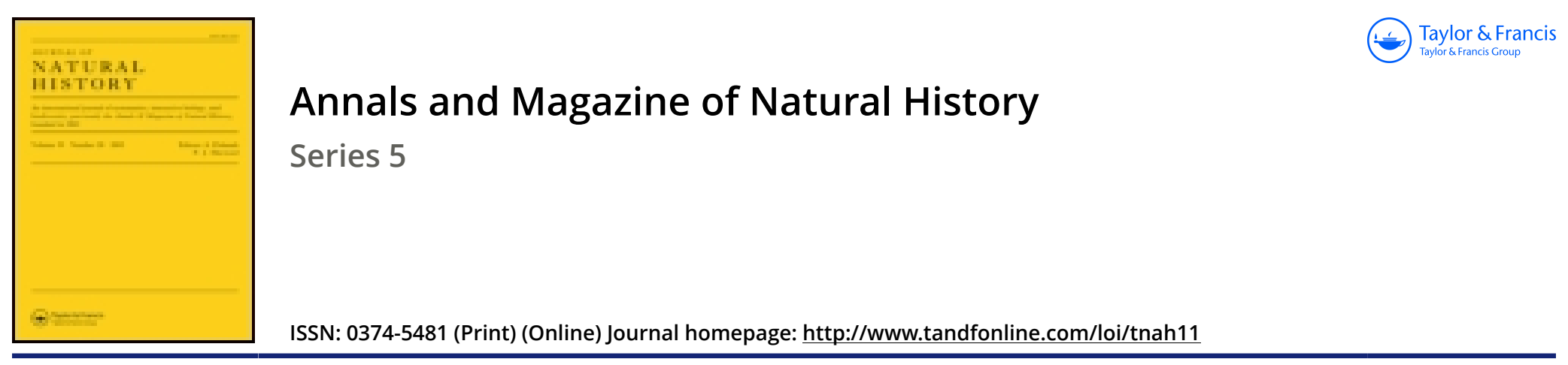

\title{
On Lernæascus nematoxys, a hitherto unknown Lernæan
}

\section{Prof. C. Claus}

To cite this article: Prof. C. Claus (1887) On Lernæascus nematoxys, a hitherto unknown Lernæan , Annals and Magazine of Natural History, 19:111, 241-242, DOI: 10.1080/00222938709460233

To link to this article: http://dx.doi.org/10.1080/00222938709460233

$$
\text { 册 Published online: } 12 \text { Oct } 2009 .
$$

Submit your article to this journal $\sqsubset \pi$

WII Article views: 2

Q View related articles $₫$ 
resembled them, he proposed for them a now genus, which he ealled Titanosalurus. Two species were represented. After noticing the principal characters of the Indian specimens, he showed that some caudal vertebræ in the British Museum, collected by the late Mr. Fox from the Wealden of Brook, in the Isle of Wight, agreed in form with those found in India and were, in fact, intermediate in some respects betwcen the two Indian species. An inquiry into the associated remains at Brook indicated that the caudal vertebre in question probably belonged to Omithopsis, and this probability was supported by the structure of certain American fossil genera placed by Marsh in the same suborder, Sauropoda, of the Dinosauria. In any case there is great probability that at least one of the Indiau and the Isle of Wight vertebræ should be roferred to the same genus.

Some other instances of fossil vertebrates appearing in Indian beds of a rather later geologieal age than in Europe were noticed.

\section{MISCELLANEOUS. \\ On Lernxascus nematoxys, a hitherto unknown Lernaean. By Yrof. C. Ceaus.}

Blinfati the scales, especially of the pigmented side, of Solet monochir there lives a vermiform parasite 8-10 millim. long, which, when examined by the naked eye, resembles a small Nematode; it glides to and fro by means of slight bendings of its body, after the fashion of the mining caterpillars, in short, narrow, mucous cauals. Closer examination, however, shows that we have to do here with a female Lernæan, which has taken on a worm-like form in accordance with its dwelling-place, and has acquired several exceedingly remarkable adaptations. The anterior and posterior extremities of the body taper off gradually, the former easily recognizable by the insertion of the antennæ, the latter by the two furcal processes. As way be seen from the position of the two oviducal apertures, only the extreme hinder end, scarcely 1 millim. long, represents the audomen; the preceding division of the body, which is nearly ten times as long, with the nervous ccntre, middle intestine, ovaries, and cement-glands, represents the cephalothorax. On the cephalio part of this the anterior, setigerous, tactilo antenna are inserted; and ventrally the prehensile antennæ, which terminate in strong hooks. The tripartite entomostracal eye is perfectly retained. The mouth-organs consist of a sucking-proboscis armed with two reversed hooklets, and of two powerful foot-jaws. The mandibles are aborted, and the stylet-bristles placed outside of the proboseis are to be regarded as maxilla. There are three pairs of limbs consisting of minute rudimentary feet originating far apart; the first two pairs are still recognizably biramose; the feet of the last pair 
are simple wart-like tubercles, each furnished with two setæ. As a character acquired by adaptation and quite peculiar to the genus, special interest appears to attach to the presence of about fifty pairs of dorsal, and the same number of ventral, scale-like, finely striated elevations, which are obliquely elevated and extend over the whole length of the thorax to the commencement of the abdomen, and are of essential service in the gliding-movements beneath the scales of the fish. To these is added, at the anterior end of the head, a median dorsal tubercle, which is elothed transversely with close-set chitinous bands, and probably aids in the boring and mining movements.

Although there could be no doubt that in the parasite here described we had to do with a female Lernæan in the egg-producing stage, the search for younger and smaller forms led at once to an acquaintanco with the males and females in the copulatory stage. In this phase of development the sexual animals attain scarcely one third of the length of the preguant female, and nearly approach the type of the free-swimming jointed Copepoda. The larger malcs have retained nearly the normal segmentation of the body, and possess two pairs of swimming-feet modified for clinging, followed on the third pectoral segment by a third pair of simple stumps. The smaller and more feebly constructed female shows exactly the same construction of body, except that the segmentation becomes quite retrograde in the thorax and abdomen, which latter tapers towards the extremity and runs out into two furcal joints. In the male animal the thorax consists of fire, and the abdomen of four sharply separated segments, of which the genital segment is unusually large, but nevertheless it is exceeded in size by the terminal segment. Tho latter appears almost scutiform and considerably elengated, in connexion, as may be at once ascertained, with the position of the testes, which are moved down into the terminal segment-a very interesting change of position quite unknown to me in any casc elsewhere among the Copepoda, but which has become normal in the nearly allied Argulidæ, formerly referred erroneously to the I'byllopoda. The spermatophores are remarkable for their extraordinary size, not only filling the genital segment, which is furnished with two plates, but extending forwurd nearly to the limit of the antepenultimate thoracic segment. The prehensile antennæ, in the copulatory stage, show the type of the Corycæidæ, and become afterwards very essentially simplified in the females; the parts of the mouth also differ considerably from the form in the pregnant stage, inasmuch as they are destitute of the sucking-proboscis, and possess a different form of the maxillary foot-pair, agreeing in the two sexes. The presence of two wing-like plates on the back of the second thoracic segment seems worthy of notice; they remind one of the characters of the group Pandaridx. In the female these become considerably retrograde, but are still retained even in the fog-producing stage as two-pointed chitinous pieces.-Anzeiyer $k$. Alad. Wiss. in Wien, December 2, 1886, p. 231. 